\section{AB1071 AUTO-IMMUNE AND INFLAMMATORY DISEASES IN CHILDREN WITH SICKLE CELL DISEASE: DIAGNOSTIC AND THERAPEUTIC ISSUES}

Caroline Vinit ${ }^{1}$, Corinne Guitton ${ }^{2}$, Patricia Benhaim ${ }^{1}$, Florence Missud ${ }^{3}$, Mariane De Montalembert ${ }^{4}$, Lahoueri Amor ${ }^{1}$, Cécile Arnaud ${ }^{5}$, Oussama Charara ${ }^{6}$, Vincent Gajdos ${ }^{7}$, Véronique Hentgen ${ }^{6}$, Annie Kamdem ${ }^{5}$, Sylvie Nathanson ${ }^{6}$, Brigitte Bader-Meunier ${ }^{4}$, Isabelle Melki ${ }^{3}$, Isabelle Koné-Paut ${ }^{2}$, Pierre Quartier ${ }^{4}$, Loic De Pontual ${ }^{1}$, Luu-Ly Pham ${ }^{1} .{ }^{1}$ J.Verdier hospital, Bondy, France; ${ }^{2}$ Bicêtre hospital, Kremlin Bicêtre, France; ${ }^{3}$ R.Debré hospital, Paris, France; ${ }^{4}$ Necker hospital, Paris, France; ${ }^{5} \mathrm{CHIC}$, Créteil, France; ${ }^{6}$ A.Mignot Hospital, Versailles, France; ${ }^{7}$ A.Béclère Hospital, Clamart, France

Background: Coexistent auto-immune and inflammatory diseases (AIID) and sickle cell disease (SCD) have been recently described in adults and children, however its frequency and physiopathology remain unclear (1-6).

Objectives: The aim of this study is the analysis of clinical and biological characteristics at AIID diagnosis and the evolution under treatment in children with SCD

Methods: Between May 1991 and March 2018, 35 of 3,800 SCD children diagnosed with AID in seven hospitals in Paris and suburb were analyzed in a retrospective survey.

Results: Thirty-five patients reported 44 AlID: auto-immune liver disease (AILD, $n=13)$, inflammatory bowel disease (IBD, $n=7)$, juvenile idiopathic arthritis (JIA, n=6), systemic lupus erythematosus $(n=5)$, autoimmune hemolytic anemia ( $n=3)$, Sjögren's syndrome $(n=2)$, histiocytic necrotizing lymphadenitis $(n=2)$, vasculitis $(n=2)$, myasthenia gravis $(n=2)$, sarcoidosis $(n=2)$, inflammatory uveitis $(n=1)$, sclerodermia/juvenile dermatomyositis $(n=1)$. Median age at diagnosis was 10 [2 - 18] years. The mean delay between first symptom and diagnosis was $15.5( \pm 29)$ months. The time of diagnostic was significantly longer for patients with JIA compared to other AID (63 versus 10 days, $p=0.004$ ). Sixteen patients $(45.7 \%$ ) had hypergammaglobulinemia $>20 \mathrm{~g} / \mathrm{L}$ at diagnosis. AlLD had a hypergammaglobulinemia at the time of diagnosis $(30.0 \mathrm{~g} / \mathrm{L})$, with a statically significant decrease at the end of follow-up (18.2g/L, $p=0,0048$ ). Among 21 patients $(60 \%)$ treated with systemic steroids, it triggered vaso-occlusive crisis in $14(66.7 \%)$, one acute chest syndrome, one transient ischemic attack. Thirteen of 35 patients $(37.1 \%)$ were managed with biotherapy for AIID, well tolerated. Three patients $(8.6 \%)$ underwent stem cell transplantation, one died of a cortico-resistant and multipolar graft versus host reaction, two were cured of both AIID and SCD. Nine severe infections were reported, four under steroids, five under biotherapy.

Conclusion: Diagnosis and therapeutic care of coexistent auto-immune and inflammatory diseases are difficult and challenging in children with SCD. Annual monitoring of inflammatory markers could be recommended to detect AIID earlier and prevent diagnostic delay in case of high ascension in SCD patients.

\section{REFERENCES}

[1] Li-Thiao-Te V, Uettwiller F, Quartier P, et al. Coexistent sickle-cell anemia and autoimmune disease in eight children: pitfalls and challenges. Pediatr Rheumatol Online J. 17 janv 2018;16(1):5.

[2] Cherner M, Isenberg $D$. The overlap of systemic lupus erythematosus and sickle cell disease: report of two cases and a review of the literature. Lupus. juin 2010;19(7):875-83.

[3] Adelowo O, Edunjobi AS. Juvenile idiopathic arthritis coexisting with sickle cell disease: two case reports. BMJ Case Rep. 1 déc 2011;2011.

[4] Michel M, Habibi A, Godeau B, Bachir D, Lahary A, Galacteros F, et al. Characteristics and outcome of connective tissue diseases in patients with sickle-cell disease: report of 30 cases. Semin Arthritis Rheum. déc 2008;38(3):228-40.

[5] Galmiche S, Amiot X, Georgin-Lavialle S, et al. Maladies inflammatoires chroniques de l'intestin chez des patients atteints de syndrome drépanocytaire majeur : à propos de 6 cas. Disponible sur: http://www.em-premium. com.frodon.univ-paris5.fr/article/1122766/resultatrecherche/34

[6] Jitraruch S, Fitzpatrick E, Deheragoda M, et al. Autoimmune Liver Disease in Children with Sickle Cell Disease. J Pediatr. oct 2017;189:79-85.e2.

Disclosure of Interests: Caroline Vinit: None declared, Corinne Guitton: None declared, Patricia Benhaim: None declared, Florence Missud: None declared, Mariane De Montalembert: None declared, Lahoueri Amor: None declared, Cécile Arnaud: None declared, Oussama Charara: None declared, Vincent Gajdos: None declared, Véronique Hentgen Consultant for: SOBI, Novartis, Abbvie, Speakers bureau: Novartis, Annie Kamdem: None declared, Sylvie Nathanson: None declared, Brigitte Bader-Meunier: None declared, isabelle melki: None declared, Isabelle Koné-Paut Grant/ research support from: $\mathrm{SOBI}$ has supported drug product (anakinra) for the presented study, Consultant for: SOBI, Novartis, Pfizer, Abbvie, UCB CHUGAI, ROCHE, Pierre Quartier Consultant for: AbbVie, Chugai-Roche, lilly, Novartis, Novimmune, Sanofi, and SOBI, Consultant for: AbbVie, Chugai-Roche, Lilly, Novartis, Novimmune, Sanofi, and SOBI, Speakers bureau: AbbVie, BMS, Chugai-Roche, Novartis, Pfizer, and SOBI, Speakers bureau: AbbVie, BMS, Chugai-Roche, Novartis, Pfizer, and SOBI, Loic De Pontual: None declared, Luu-Ly Pham: None declared DOI: 10.1136/annrheumdis-2019-eular.4097

\section{AB1072 UVEITIS IN PEDIATRIC RHEUMATOLOGY: TERTIARY CENTER EXPERIENCE IN TURKEY}

Zahide Ekici Tekin ${ }^{1}$, Gulcin Otar Yener ${ }^{1}$, Ebru Nevin Çetin ${ }^{2}$, Selen Akbulut ${ }^{2}$, Selcuk Yuksel'. ${ }^{1}$ Pamukkale University Faculty of Medicine, Pediatric Rheumatology, Denizli, Turkey; ${ }^{2}$ Pamukkale University Faculty of Medicine, Ophthalmology, Denizli, Turkey

Background: Since pediatric uveitis is generally asymptomatic, the diagnosis and treatment may be mostly delayed. Severe complications and visual loss may be observed even at the initial visit. Pediatric uveitis is tend to be chronic, persistent, recurrent, and the management may be complex (1).

Objectives: The aim of this study is to report epidemiology, etiology, clinical features, management and the outcomes of non infectious pediatric uveitis at a tertiary pediatric rheumatology center in Turkey.

Methods: The clinical records of the patients with non infectious uveitis who were followed up by department of pediatric rheumatology and ophtalmology were reviewed, from January 2013 to June 2018, retrospectively. The inclusion criteria were as follows being age $\leq 16$ years following up at least 6 months in both the ophtalmology and pediatric rheumatology clinics. Uveitis was categorized anatomically according to the Standardization of Uveitis Nomenclature criteria (2).

Results: Of 37 patients (67 eyes), $45,9 \%$ were female. Mean age of onset was $8,5 \pm 4,4$ years $(1,6-15,6)$, mean follow-up was $60 \pm 42$ months $(6-191)$. The general features of uveitis were anterior, idiopathic and bilateral in this study similar to literature (Table 1). The most common systemic diseases associated with uveitis were juvenile idiopathic arthritis (JIA).Two patients improved with local medications, while the remaining 35 patients required systemic treatments such as short-time (oral/iv) corticosteroids (CS) in $94.5 \%$ of them, methotrexate (MTX) in $86.4 \%$, azathioprine (AZA) in $5.4 \%$, adalimumab (ADA) in $67.5 \%$, tocilizumab (TCB) in $2.7 \%$. In $26.1 \%$ of patients receiving ADA who did not respond to standard dose of ADA, we had to shorten the dosage intervals of ADA from every 2 weeks to every week. At least 1 ocular complication was observed in $83.7 \%$ of the patients, such as cataract, glaucoma, band keratopathy, synechiae, macular edema and retinal detachment. Four $(10.8 \%)$ patients had moderate visual loss and $6(16.2 \%)$ patients severe visual loss (3). The prevalence of surgery in our study was $18.9 \%$ for cataract and glaucoma treatment.

Conclusion: Diagnosis and management of uveitis in childhood is complicated. Despite the new medication options, the advancements in diagnosis and surgical techniques, the complications are still high. Usage of shorter dose interval of ADA may be an alternative to control of the disease in patients with unresponsive to standard dosage of ADA. However large-scale clinical trials are required to assess the efficacy and safety of this treatment.

\section{REFERENCES}

[1] Tugal-Tutkun I. Pediatric uveitis. J Ophthalmic Vis Res 2011; 6: 259-269.

[2] Jabs DA, Nussenblatt RB, Rosenbaum JT, et al. Standardization of uveitis nomenclature for reporting clinical data. Results of the First International Workshop. Am J Ophthalmol 2005; 140:509-16.

[3] World Health Organisation. Report of WHO/IAPB scientific meeting, Hyderabad, India 13-47. Childhood Blindness Prevention. WHO/PBL/87. 1999. 
Abstract AB1072 Table 1. Clinical features of patients according to the anatomical classification of uveitis.

\begin{tabular}{|c|c|c|c|c|c|c|}
\hline & & $\begin{array}{c}\text { Anterioruveitis } \\
21 \text { cases } \\
(56.8 \%)\end{array}$ & $\begin{array}{l}\text { Intermediateuveitis } \\
12 \text { cases }(32.4 \%)\end{array}$ & $\begin{array}{l}\text { Posterioruveitis } \\
1 \text { case }(2.7 \%)\end{array}$ & $\begin{array}{c}\text { Panuveitis } \\
3 \text { cases } \\
(8.1 \%)\end{array}$ & $\begin{array}{c}\text { Total } \\
37 \text { cases } \\
(100 \%)\end{array}$ \\
\hline \multirow[t]{2}{*}{ Gender } & Female & $9(24.3 \%)$ & $6(16.2 \%)$ & $1(2.7 \%)$ & $1(2.7 \%)$ & $17(45.9 \%)$ \\
\hline & Male & $12(32.4 \%)$ & $6(16.2 \%)$ & 0 & $2(5.4 \%)$ & $20(54 \%)$ \\
\hline Ocular & Unilateral & $3(8.1 \%)$ & $3(8.1 \%)$ & 0 & $1(2.7 \%)$ & 7 (18.9\%) \\
\hline involvement & Bilateral & $18(48.6 \%)$ & $9(24.3 \%)$ & $1(2.7 \%)$ & $2(5.4 \%)$ & $30(81 \%)$ \\
\hline \multirow[t]{5}{*}{ Etiology } & Idiopathic & $13(35.1 \%)$ & $11(29.7 \%)$ & 0 & $2(5.4 \%)$ & $26(70.2 \%)$ \\
\hline & JIA & $5(13.5 \%)$ & 0 & 0 & 0 & $5(13.5 \%)$ \\
\hline & BehcetDisease & 0 & $1(2.7 \%)$ & 0 & $1(2.7 \%)$ & $2(5.4 \%)$ \\
\hline & Sarcoidosis & $1(2.7 \%)$ & 0 & $1(2.7 \%)$ & 0 & $2(5.4 \%)$ \\
\hline & TINU & $2(5.4 \%)$ & 0 & 0 & 0 & $2(5.4 \%)$ \\
\hline
\end{tabular}

Disclosure of Interests: None declared

DOI: 10.1136/annrheumdis-2019-eular.5470

\section{AB1072B THE CONSEQUENCES OF THE PROVISIONAL PAEDIATRIC RHEUMATOLOGY INTERNATIONAL TRIALS ORGANISATION JUVENILE IDIOPATHIC ARTHRITIS CLASSIFICATION CRITERIA}

Vera Mars $^{1}$, Joost F. Swart ${ }^{2}$, Gabriella Giancane ${ }^{3}$, Sytze De Roock ${ }^{2}$, Anne Estmann ${ }^{3}$, Marija Jelusic ${ }^{3}$, Estefania Moreno Ruzafa ${ }^{3}$, Jaime de Inocencio ${ }^{3}$, Jelena Vojinovic ${ }^{3}$, Agustin Remesal $^{3}$, M Laday $^{3}$, Rolando Cimaz ${ }^{3}$, A V. Cochino ${ }^{3}$, Inmaculada Calvo ${ }^{3}, \mathrm{M} \mathrm{Harjacek}^{3}$, Nico Wulffraat $^{2}$, Nicolino Ruperto ${ }^{3} .{ }^{1}$ UMC Utrecht / Utrecht University, Undergraduate / Medical student, Utrecht, Netherlands; ${ }^{2}$ Wilhelmina Children's Hospital / UMC Utrecht, Pediatric Rheumatology, Utrecht, Netherlands; ${ }^{3}$ Paediatric Rheumatology International Trials Organisation, Genova, Italy

Background Last year the International League of Associations for Rheumatology (ILAR) classification criteria for juvenile idiopathic arthritis (JIA), [1] were challenged by the provisional Paediatric Rheumatology International Trials Organisation (PRINTO) classification criteria.[2] Four disorders were proposed: (a) systemic JIA; (b) rheumatoid factor (RF)-positive JIA; (c) enthesitis/spondylitisrelated JIA; and (d) early-onset antinuclear antibody (ANA)-positive JIA. Earlyonset ANA-positive JIA is defined by: arthritis for $\geq 6$ weeks, and early-onset $(\leq 6$ $y r s$ ), and presence of 2 positive ANA tests with a titer $\geq 1 / 160$ at least 3 months apart with the exclusions of having systemic JIA, RF-positive arthritis, or enthesitis/spondylitis-related JIA.

Objectives To evaluate the shifts from the original subtypes of JIA in the new disorder of early-onset ANA-positive JIA.

Methods This study used data from the international PRINTO based registry regarding pharmacovigilance in JIA called Pharmachild.[3] For this analysis we used the data of 4,165 patients completely categorized following the ILAR 'oligoarthritis', 'RF-negative polyarthritis', 'psoriatic arthritis' and 'undifferentiated JIA' (UJIA) subtypes and with complete determination of ANA status. These patients were if possible reclassified in the early-onset ANA-positive JIA according to the provisional PRINTO classification criteria.

Results Table 1 shows the characteristics of all 4,165 patients according to the ILAR criteria. Of this final set of 4165 patients, 1279 (30.7\%) were ANA-positive and 957 (74.8\%) classified into the PRINTO 'early onset ANA-positive JIA' category. Of these 957, 2 patients were RF-positive, which is an exclusion criterion for the 'early onset ANA-positive JIA' category and therefore were not categorized as early onset ANA-positive JIA. The female proportion was higher than in any ILAR subtype being $83.0 \%$ (793/955). The origin (ILAR categories) of the 955 patients in the 'early onset ANA-positive JIA' category consisted of $33.7 \%$ patients with persistent oligoarthritis (322/955), 24.7\% (236/955) with extended oligoarthritis, $28.0 \%$ with RF-negative polyarthritis (267/955), 4.2\% with psoriatic arthritis (40/ 955) and $9.4 \%$ with UJIA (90/955).

$\begin{array}{llllll} & \begin{array}{l}\text { Persistent } \\ \text { OJIA }\end{array} & \begin{array}{l}\text { Extended } \\ \text { OJIA }\end{array} & \begin{array}{l}\text { RF negative } \\ \text { PJIA }\end{array} & \begin{array}{l}\text { Psoriatic } \\ \text { arthritis }\end{array} & \text { UJIA } \\ \begin{array}{l}\text { Total number of } \\ \text { patients, } n(\%)\end{array} & 1283(30.8 \%) & 663(15.9 \%) & 1665(40.0 \%) & 210(5.0 \%) & 344(8.3 \%) \\ \begin{array}{l}\text { Age of disease } \\ \text { onset, years (IQR) }\end{array} & 4.5(2.5-8.3) & 3.7(2.3-1.7) & 6.7(2.9-11.3) & 8.6(3.4-13.3) & 5.7(2.6-10.8) \\ \text { Female, } n(\%) & 968(77.6 \%) & 541(81.6 \%) & 1283(77.1 \%) & 145(69.0 \%) & 228(66.3 \%) \\ \text { ANA positive, } n(\%) & 424(33.0 \%) & 293(44.2 \%) & 384(23.1 \%) & 51(24.3 \%) & 127(26.9 \%)\end{array}$

Table 1. Patient characteristics (4165 patients) divided in ILAR 2001 categories; correctly determined (taking all exclusion criteria into account). OJAA = oligoarticular $J A$, PJIA= polyarticular $J A$

Conclusion This study shows that of all ANA-positive JIA patients belonging to the 'oligoarthritis', 'RF-negative polyarthritis', 'psoriatic arthritis' and 'UJIA' ILAR subtypes, $74.8 \%$ met the criteria for the PRINTO 'early onset ANA-positive' category. The female proportion was higher than in any ILAR subtype being $83.0 \%$ This new category consists largely of 3 ILAR subtypes: persistent oligoarthritis (34\%), extended oligoarthritis (25\%) and RF negative polyarthritis $(28 \%)$. Further studies on these provisional criteria are ongoing.

\section{REFERENCES}

[1] Petty RE, Southwood TR, Manners P et al. International League of Associations for Rheumatology Classification of Juvenile Idiopathic Arthritis: Second Revision, Edmonton, 2001. J Rheumatol. 2014

[2] Martini A, Ravelli A, Avcin T et al. Toward New Classification Criteria for Juvenile Idiopathic Arthritis: First Steps, PRINTO International Consensus. J Rheumatol. 2018 Oct 1

[3] Swart J, Giancane G, Horneff G et al. Pharmacovigilance in juvenile idiopathic arthritis patients treated with biologic or synthetic drugs: combined data of more than 15,000 patients from Pharmachild and national registries. Arthritis Res Ther. 2018 Dec 27

Disclosure of Interests Vera Mars: None declared, Joost F. Swart: None declared, Gabriella Giancane: None declared, Sytze De Roock: None declared, Anne Estmann: None declared, Marija Jelusic: None declared, Estefania Moreno Ruzafa: None declared, Jaime de Inocencio: None declared, Jelena Vojinovic: None declared, Agustin Remesal: None declared, M Laday: None declared, Rolando Cimaz: None declared, A V Cochino: None declared, Inmaculada Calvo Grant/research support from: received research grants from Pfizer, Roche, Novartis, Clementia, Sanofi, MSD, BMS and GSK, Consultant for: Advisory boards: Novartis, AbbVie, Speakers bureau: AbbVie, Roche, Novartis, SOBI, M Harjacek: None declared, Nico Wulffraat: None declared, Nicolino Ruperto Grant/research support from: The Gaslini Hospital, where NR works as full-time public employee, has received contributions ( $>10.000$ USD each) from the following industries in the last 3 years: BMS, Eli-Lilly, GlaxoSmithKline, F Hoffmann-La Roche, Janssen, Novartis, Pfizer, Sobi. This funding has been reinvested for the research activities of the hospital in a fully independent manner, without any commitment with third parties., Consultant for: Received honoraria for consultancies or speaker bureaus ( $<10.000$ USD each) from the following pharmaceutical companies in the past 3 years: Ablynx, AbbVie, Astrazeneca-Medimmune, Biogen, Boehringer, BristolMyers Squibb, Eli-Lilly, EMD Serono, GlaxoSmithKline, Hoffmann-La Roche, Janssen, Merck, Novartis, Pfizer, R-Pharma, SanofiServier, Sinergie, Sobi and Takeda., Speakers bureau: Received honoraria for consultancies or speaker bureaus (< 10.000 USD each) from the following pharmaceutical companies in the past 3 years: Ablynx, AbbVie, Astrazeneca-Medimmune, Biogen, Boehringer Bristol-Myers Squibb, Eli-Lilly, EMD Serono, GlaxoSmithKline, Hoffmann-La Roche, Janssen, Merck, Novartis, Pfizer, R-Pharma, SanofiServier, Sinergie, Sobi and Takeda.

DOI: 10.1136/annrheumdis-2019-eular.1958

\section{AB1072C CHILDREN WITH JUVENILE IDIOPATHIC ARTHRITIS THE CORRELATION BETWEEN CAROTID INTIMA-MEDIA THICKNESS AND MARKERS OF INFLAMATION TO DETERMINE PRE-CLINICAL ATHEROSCLEROSIS}

Mustafa Armut ${ }^{1}$, Ruhan Düşünsel ${ }^{2}$, Aysenur Pac Kisaarslan ${ }^{2}$, Gonca Koç ${ }^{3}$, Betül Sözeri ${ }^{2}$, Ferhan Elmalı ${ }^{4}$, Muammer Hakan Poyrazoglu ${ }^{2}$, Zubeyde Gunduz ${ }^{2}$. ${ }^{1}$ Erciyes University Faculty of Medicine, Pediatrics, Kayseri, Turkey; ${ }^{2}$ Erciyes University Faculty of Medicine, Pediatric Rheumatology, Kayseri, Turkey; ${ }^{3}$ Erciyes University Faculty of Medicine, Pediatric Radiology, Kayseri, Turkey, ${ }^{4}$ izmir Katip Celebi University, Bioistatistic, Izmir, Turkey

Background: Juvenile idiopathic arthritis (JIA) is the most common chronic rheumatic disease in childhood. JIA is a heterogeneous group of disorders with different disease progression and prognosis. Cardiovascular 